\title{
Azmat Gani* and Saeed Al-Muharrami The Effect of Institutional Quality on Bank Lending in the Gulf Cooperation Council Countries
}

DOI 10.1515/rmeef-2015-0032

Published online April 27, 2016

\begin{abstract}
This paper examines the effect of institutional quality on lending by banks in Gulf Cooperation Council (GCC) group of countries. The methodology included the estimation of a reduced form regression equation utilizing cross country data for a range of variables capturing institutional quality. The empirical findings provide evidence that conventional institutional quality measured by: the time taken to enforce a contract, regulatory quality, the rule of law and government effectiveness; are inversely correlated with the lending by the banks, among other factors. Interestingly, our findings revealed that Sharia financing legislation to be positive and statistically significantly correlated with bank lending. Our main policy implication is that strengthening the domestic conventional institutional quality in the GCC countries is vital in order to facilitate effective lending by banks.
\end{abstract}

Keywords: GCC countries, banks, Sharia, lending, institutions JEL codes: G21, G28, 022

\section{Introduction}

This paper investigates the effect of institutional quality on lending by the banking sector in the GCC countries. It is now well known that the global financial and economic crisis (GFC) that originated in the USA in 2007 (reviewed in Duttagupta and Cashin 2011), severely strained the global financial and economic system of several advanced economies. One of the major causes for the GFC was institutional weakness among other factors. Among the GCC, the effects of the GFC were not as severe as experienced by the advanced countries like Greece and Spain. A study by Al-Hassan, Khamis, and Oulidi (2010)) revealed that despite the strengths of the GCC financial sector there are

\footnotetext{
*Corresponding author: Azmat Gani, Department of Economics and Finance, College of Economics and Political Science, P.O. Box 20. Al Khod 123, Muscat, Oman, E-mail: azmat@squ.edu.om
}

Saeed Al-Muharrami, Department of Economics and Finance, College of Economics and Political Science, P.O. Box 20. Al Khod 123, Muscat, Oman, E-mail: muharami@squ.edu.om 
weaknesses with their financial sector largely with their operational aspects. The weaknesses also pertain to the institutional issues and this is an area that needs further examination.

Among other factors, weaknesses in institutional quality (law and order, regulations, contracts; government effectiveness, judiciary, corruption and cronyism and traditions of civic responsibility) can impact the functioning as well as the performance of the financial sector, amongst other economic outcomes. With the aim of pursuing greater financial integration in the globalizing world, the GCC countries: Bahrain, Kuwait, Oman, Qatar, Saudi Arabia and United Arab Emirates; have taken a range of economy wide reforms through introducing new legislations pertaining to their business environment. A unique feature of the GCC financial sector is rapid growth in Islamic financial services that has provided Sharia compliant financing. GCC's Islamic financial services are now playing an integral role in their economies. The resilience shown by the GCC banking sector in face of the GFC could also be attributable to Islamic financial services. Together with the Sharia compliant financing, the quality of conventional institutions (contract enforcements, regulatory quality, the rule of law and government effectiveness, among others) forms an integral part of the banking system in the GCC and so analyzing the relationship between achievements in institutional quality and bank lending can provide useful guide to financial policy makers in terms of having strong institutional mechanisms to safeguard the banking and the financial sector in the event of unforeseen developments in the banking system. A systematic analysis of the effects of institutional quality and bank lending is worth exploring as studies quantifying these types of effects are rare for the GCC economies.

This paper is divided into four sections. The next section outlines the analytical model and discusses the choice of variables. Section three presents the findings. Section four concludes.

\section{Model and the Choice of Variables}

The quality of institutions is an important element influencing the financial development in many countries. For example, Levine (2005) noted that the legal and accounting reform that strengthen creditor rights, contract enforcement and accounting practices boost financial development while Mishkin (2009) argued that a poorly designed legal system makes it more difficult for lenders to enforce restrictive covenants. Another significant study by Djankov, McLiesh, and Shleifer (2007)) revealed that creditor protection through the legal 
system and information sharing institutions are associated with higher ratios of private credit to gross domestic product.

The GCC group of countries is overwhelmingly Muslim population dominated by Islamic sharia law upon which the Islamic way of life and social justice is formulated. One of the outstanding features that characterize the GCC financial sector is the rapidly expanding Islamic financial services in a variety of areas including retail and investment banking, insurance and fund management. The GCC countries established Islamic way of doing business including Islamic finance through passing decrees several years ago. The legal framework within which Islamic way of doing business and financing is the Sharia law the legal system based in Islam. There are three core Sharia sources: the Quran (the principle source of Islam including the word of God as delivered to Prophet Mohammed); the Hadith (the narrative words of the actions and sayings of the prophet himself); and the Ijtihad (the derivation and the formulation of Sharia laws or guidelines by qualified scholars to deduct further knowledge form the Quran and the Hadith).

In terms of financial transactions, the Sharia compliant finance does not allow for the charging of the interest payments (riba) as only goods and services are allowed to carry a price. In addition, it does not allow for speculation and prohibits financing of specific illicit activities. Sharia compliant financing relies on the idea of profit and loss and thus risk sharing, on both the liability and the asset side and posits that all transactions have to be backed by real economic transactions that involves tangible assets. In practice, Islamic banks financial trading is asset based and asset driven because they are prohibited from dealing with interest and Islamic equity investments have Sharia based screens that restrict investment in certain economic activities (Bashir 1983). On the contrary, conventional banks are interest based and debt driven. The Islamic financing activities are usually concentrated in real and tangible investment activities such investments in technology, telecommunications, steel, energy, transportation and logistics, health care, utilities, construction and real estate (Abd Rahman 2010).

While the state takes the centralized role of managing the political and economic affairs of the nation, the GCC institutional environment, both political and business, is largely dominated by classical Islamic Sharia law. All the GCC countries while upholding the underlying values of Islamic social justice, modern practices of commercial business and transactions is seen throughout these countries as a result of the open nature of their economies as well as the desire for international economic integration and competitiveness.

Much of the regulatory and operational aspects of Islamic banking are under the authority of the Central Banks which provides the legislative framework 
for competition within the Islamic financial sector. The legislations also contain provisions for Islamic financial governance where each financial institution hosts a Sharia compliant board. Detailed discussion of the Sharia governance systems can be found in Wilson (2009). The Sharia board is the key feature of their governance. According to Mollah and Zaman (2015), the Sharia board represents a layer of governance. The Sharia board has a variety of roles including advising the board of directors; providing input to Islamic financial institutions on Sharia matters; setting Sharia related rules and principles and ensuring that policies and procedures prepared by the Islamic financial institutions are in conformity with Sharia and issuing verdict (fatwa) to create confidence with respect to Sharia compliance (Safieddine 2009). Together with regular boards of directors and routine executive and other operational committees, the Sharia board may restrain boards of directors and management from engaging in aggressive lending and major risk taking activities and averse to unethical practice and ensure compliance and principles of sharia thus contributing to social justice (Mollah and Zaman 2015).

We hypothesize that the role of Sharia compliant financing is likely to be a contributory factor in the resilience as well as the efficiency GCC domestic banks as well as the functioning of their overall financial sector. We attempt to model and capture this effect of the role of modern Islamic institutions together with conventional institutional quality through a general model explaining bank lending in the GCC countries as expressed in equation (1).

$$
B L_{i, t}=\zeta_{0}+\zeta_{1} R I_{i t}+\zeta_{2} P C G D P_{i t}+\zeta_{3} G C_{i t}+\zeta_{4} S L_{i t}+\Pi^{1} I_{i t}^{1}+\eta_{i, t}+\varepsilon_{i, t}
$$

where, $B L$ is the ratio of domestic credit by banks to gross domestic product; $R I$ is the lending real interest rate; $P C G D P$ is the per capita gross domestic product (PPP constant 2005 US dollars); GC is the ratio of government final consumption expenditures to gross domestic product; and $S L$ is Sharia legislation measured by a dummy variable (1 for Sharia legislation on banking and finance and 0 otherwise). $I$ is the indicator of institutional quality variables. There are four measures of $I$ : the time taken to enforce a contract $(C T)$, the regulatory quality $(R Q)$, the rule of law $(R L)$, and government effectiveness $(G E)$; $\eta$ is the country-specific unobserved factor, and $\varepsilon$ is the regression error term. Subscripts $i(i=1, \ldots, N)$ and $t(t=1, \ldots, T)$ are country and time respectively. Combining these assumptions means estimating a cross-sectionally heteroskedastic and time-wise autoregressive model where the error terms have the following properties:

$E\left(\varepsilon_{i, t}^{2}\right)=\sigma_{i}^{2}$ (heteroskedasticity); $E\left(\varepsilon_{i, t} \varepsilon_{j, t}\right)=0$ for $i \neq j$ (cross-sectional independence); and $\varepsilon_{i, t}=\rho_{i} \varepsilon_{i, t-1}+e_{i, t}$ (auto-regression), where, $e_{i, t} \sim N\left(0, \sigma_{e, i}^{2}\right)$; 
$\varepsilon_{i, 0} \sim N\left[0, \sigma_{e i}^{2} /\left(1-\rho_{i}^{2}\right)\right]$; and $E\left(v_{i t-1} e_{t}\right)=0$ for all $i, j$. The justification of the right hand side variables in equation (1) is discussed below.

The inclusion of the $R I$ follows the neoclassical argument that high interest rates (lending) increases the user cost of capital and so reduces investment. Banks prefer to expand their operations in countries with a larger economic size (Brealey and Kaplanis 1996) and the inclusion of PCGDP is that as incomes increase, it signals banks of an expanding economy. GC can impact bank credit expansion if government borrows from the domestic financial markets which could amplify financial crowding out (Hauner 2008) thus imposing a negative effect on the deepening of the banking sector.

The inclusion of CT follows the argument by Djankov, Glaeser, La Porta, Lopez-de-Silanes and Shleifer (2003): that the legal systems that protect investors by enforcing contracts effectively boost financial development. On the contrary, the absence of a legal mechanism for enforcing business contracts can lead to fewer financial transactions. Variable $R L$ builds on the argument by Law and Azman-Saini (2012) who shows that high-quality institutional environment is important in explaining the development of the banking sector in the developing countries. As such improved rule of law can influence the provision of credit by banks within the domestic economy. The hypothesis for $R Q$ is that banks that formulate effective and enforceable regulations in safe guarding the interests of the borrowers as well as the banks as Stigler (1971) argued that for their interest producers tend to be more influential in shaping regulatory legislation. Banks are less likely to expand when stringent regulations are placed on bank entry. GE is included with the view that the quality of public services and civil services with absence of bureaucracy can impose positive external effects on domestic banking activities.

CT is the number of days from the filing of the law suit in a court until the final determination and, in appropriate cases, payment. The source of data is the World Bank's (2013) Doing Business Report 2013. Variables RL, RQ and GE are defined by Kaufmann, Kray, and Mastruzzi (2012) and are measured on a scale ranging from -2.5 (weak) to 2.5 (strong). $R L$ captures the extent to which agents have confidence in and abide by the rules of society, and in particular the quality of contract enforcement, the police, the courts, as well as the likelihood of crime and violence. $R Q$ captures the ability of government to formulate and implement sound policies and regulations and promote private sector development. GE reflects perceptions of the quality of public services, the quality of the civil service and the degree of its independence from political pressures, the quality of policy formulation and implementation, and the credibility of the government's commitment to such policies. 


\section{Empirical Findings}

Our analysis incorporates annual data for years 2003-2012 for four GCC countries (Bahrain, Kuwait, Oman and Qatar) and estimated in several specifications so as to avoid the commonly known multicollinearity or the overlapping problem among the CT, RQ, RL and GE. Two of the GCC countries (Saudi Arabia and United Arab Emirates) were not included in the estimation phase due to missing data on real interest rate. Table 1 presents the empirical results of the log-linear model where the measures of institutional quality are successively added to the

Table 1: Empirical results.

\begin{tabular}{|c|c|c|c|c|}
\hline Variables & Specification 1 & Specification 2 & Specification 3 & Specification 4 \\
\hline PCGDP & $\begin{array}{l}-0.916 \mathrm{E}-05 \\
(4.420)^{\star}\end{array}$ & $\begin{array}{l}-0.683 \mathrm{E}-05 \\
(6.240)^{\star}\end{array}$ & $\begin{array}{l}-0.362 \mathrm{E}-05 \\
(2.271)^{\star \star}\end{array}$ & $\begin{array}{c}-0.520 \text { E05 } \\
(4.314)^{\star}\end{array}$ \\
\hline$G C$ & $\begin{array}{l}0.028 \\
(2.501)^{\star \star}\end{array}$ & $\begin{array}{c}0.034 \\
(3.447)^{\star}\end{array}$ & $\begin{array}{c}0.044 \\
(5.331)^{\star}\end{array}$ & $\begin{array}{c}0.041 \\
(4.082)^{\star}\end{array}$ \\
\hline$R I$ & $\begin{array}{c}0.034 \\
(1.211)\end{array}$ & $\begin{array}{c}0.027 \\
(0.966)\end{array}$ & $\begin{array}{c}0.312 \\
(1.270)\end{array}$ & $\begin{array}{l}0.059 \\
(1.946)^{\star \star \star}\end{array}$ \\
\hline$S L$ & $\begin{array}{c}0.676 \\
(2.250)^{\star}\end{array}$ & $\begin{array}{c}0.636 \\
(10.930)^{\star}\end{array}$ & $\begin{array}{c}0.592 \\
(10.780)^{\star}\end{array}$ & $\begin{array}{c}0.636 \\
(10.330)^{\star}\end{array}$ \\
\hline$C T$ & $\begin{array}{c}-0.002 \\
(1.521)\end{array}$ & $\ldots$ & $\ldots$ & $\ldots$ \\
\hline$R Q$ & $\ldots$ & $\begin{array}{c}-0.118 \\
(1.117)\end{array}$ & $\ldots$ & $\ldots$ \\
\hline$R L$ & $\ldots$ & $\ldots$ & $\begin{array}{l}-0.429 \\
(2.291)^{\star \star}\end{array}$ & $\ldots$ \\
\hline$G E$ & $\ldots$ & $\ldots$ & $\ldots$ & $\begin{array}{l}-0.215 \\
(2.571)^{\star}\end{array}$ \\
\hline \multicolumn{5}{|l|}{ Model selection: } \\
\hline$N$ & 40 & 40 & 40 & 40 \\
\hline$F$ & 10334.88 & 10238.60 & 13511.79 & 8795.7 \\
\hline Adjusted $R^{2}$ & 0.84 & 0.88 & 0.88 & 0.86 \\
\hline Rho & 0.09 & 0.11 & 0.14 & 0.234 \\
\hline GCV & 0.47 & 0.45 & 0.46 & 0.477 \\
\hline Schwarz criterion & 0.36 & 0.67 & 0.86 & 0.77 \\
\hline Akaike criterion & 0.52 & 0.45 & 0.45 & 0.469 \\
\hline DW Statistics & 1.68 & 1.63 & 1.54 & 1.369 \\
\hline Von Neuman & 1.70 & 1.67 & 1.59 & 1.404 \\
\hline
\end{tabular}

*, **, and $* * *$ indicates statistically significant at the 1,5 and $10 \%$ levels respectively. ... indicates variable not estimated. 
control variables. The fit of the model is satisfactory given the use of pooled crosscountry data. Several of the diagnostics tests as shown at the bottom of Table 1 show that the model outcomes are satisfactory. Some of the institutional variables tested revealed results as per the theoretical expectations as discussed below.

The results in Table 1 indicate that the coefficient $S L$ is consistently positive and statistically significant at the $1 \%$ level and consistent with our theoretical expectations. The positive relationship between Sharia compliant financing legislation and bank lending strongly supports the case that there is a strong bearing on the relevance of Sharia principles to financing with less systemic risks. The findings lead to the suggestion that Sharia legislation has pro-actively facilitated bank lending. The recent experience of the GFC has shown that excessive lending and the lack of adequate financial market discipline in the conventional banking sector. Our findings of Sharia legislation indicates that the principles of Islamic financing introduced better discipline in the GCC banking sector and thus their banking activities expanded with more lending by the banks.

The results in Table 1 indicate that the coefficients of $C T, R Q, R L$ and GE are all negative. The inverse correlation of all four measures of institutional quality suggests that low levels of achievements in institutional quality have an adverse effect on bank lending. In particular, coefficients $R L$ and $G E$ are negative and statistically significant at the 5 and $10 \%$ levels respectively. The inverse effect of $R L$ suggests weaknesses in the rule of law could have adversely affected bank lending. Thus, strengthening the rule of law can deliver a positive effect in the provision of credit by banks within the domestic economy. Similarly, the negative and statistically significant effect of government effectiveness indicates its regressive effect on bank lending. This finding leads to the suggestion that an efficient and less bureaucratic public sector with an efficient civil service can deliver beneficial effects on domestic banking activities while an ineffective public sector can be a constraint in effective delivery of banking services. Overall, our findings for the conventional institutional quality variables suggest that high-quality institutional environment is important in explaining the development of the banking sector in the developing countries.

Turning to the control variables, the coefficient PCGDP has the negative sign contrary to the theoretical expectations. The negative effect is consistent across the four different equations tested. The coefficient GC is positive and statistically significant in all of the four specifications. This finding shows that rising government consumption has been positively associated with bank deepening. In regard to this, it is worth pointing out the ownership structure of the GCC banks matters much in terms of banks' lending activities to the state and its investment activities. The GCC banking sector is largely domestically owned by domestic shareholders with a significant public as well as quasi-public sector ownership. Al-Hassan, 
Khamis, and Oulidi (2010)) noted that the public and quasi-public sector ownership ranged between $13 \%$ in Kuwait to $52 \%$ in the United Arab Emirates. Given this nature of bank ownership, the positive and statistically significant correlation between government consumption and bank lending is not surprising.

\section{Conclusion}

This paper investigated the effect of institutional quality on bank lending in the GCC countries. The findings provide evidence that the four measures of institutional quality: the time taken to enforce a contract, regulatory quality, the rule of law and government effectiveness; are inversely correlated with bank lending. Among these four measures, our findings showed that the rule of law and government effectiveness were also statistically significant. Our results also revealed statistically significant and positive correlation between Sharia financing legislation and bank lending thus introducing better discipline in the GCC banking sector and facilitating more bank lending. Our findings indicate that while Sharia compliant financing has demonstrated its beneficial effects, improving conventional dimensions of institutional quality such as the rule of law and government effectiveness are also equally important as they also form an integral part of enhancing lending by the banks in the GCC countries. The main policy implication is that the GCC governments and policy makers need to play a stronger role in strengthening their institutional quality such as those identified in this study through appropriate legislations and continuous reforms of laws and regulations governing the banking and the financial sector as well as the wider economy. While the GCC countries are engaged in reforming their business environment and making it more competitive, it is vital that equal attention is paid in terms of strengthening the institutional framework within which the financial sector operates.

\section{References}

Abd Rahman, Z. 2010. Contracts and Products of Islamic Banking. Kuala Lumpur, MY: CERT Publications.

Al-Hassan, A., M. Khamis, and N. Oulidi. 2010. The GCC banking sector: topography and analysis, IMF Working Paper No. WP/10/87, International Monetary Fund.

Bashir, B. A. 1983. "Portfolio Management of Islamic Banks: Certainty Model." Journal of Banking and Finance 7:339-54.

Brealey, R. A., and E. C. Kaplanis. 1996. "The Determination of Foreign Banking Location.” Journal of International Money and Finance 15:577-97. 
Djankov, S., C. McLiesh, and A. Shleifer. 2007. “Private Credit in 129 Countries.” Journal of Financial Economics 84 (2):299-329.

Djankov, S., E. Glaeser, R. La Porta, F. Lopez-de-Silanes, and A. Shleifer. 2003. "The New Comparative Economics." Journal of Comparative Economics 31:595-619.

Duttagupta, R., and P. Cashin. 2011. "Anatomy of Banking Crises in Developing and Emerging Market Countries." Journal of International Money and Finance 30:354-76.

Hauner, D. 2008. “Credit to Government and Banking Sector Performance." Journal of Banking and Finance 32:1499-507.

Kaufmann, D., A. Kray, and A. Mastruzzi. 2012. World Wide Governance Indicators. Washington, D.C: World Bank. Available online at: http://info.worldbank.org/governance/wgi/index. asp.

Law, S. H., and W. N. W. Azman-Saini. 2012. "Institutional Quality, Governance and Financial Development." Economics of Governance 13:217-36.

Levine, R. 2005. "Finance and Growth: Theory, Mechanisms and Evidence." In Handbook of Economic Growth, edited by P. Aghion and S. N. Durlauf, 865-923. Amsterdam: Elsevier.

Mishkin, F. S. 2009. "Globalization, Macroeconomic Performance and Monetary Policy." Journal of Money, Credit and Banking 41 (1):187-96.

Mollah, S., and M. Zaman. 2015. "Shari'ah Supervision, Corporate Governance and Performance: Conventional Vs. Islamic Banks." Journal of Banking and Finance 58:418-35.

Safieddine, A. 2009. "Islamic Financial Institutions and Corporate Governance: New Insights for Agency Theory." Corporate Governance: An International Review 17:142-58.

Stigler, G. J. 1971. "The Theory of Economic Regulation." Bell Journal of Economics and Management Science 2:3-21.

Wilson, R. 2009. The Development of Islamic Finance in GCC. Durham University, UK: The Centre for the Study of Global Governance.

World Bank (2013). “Doing Business 2013.” Smarter Regulations for Small and Medium Size Enterprises, The World Bank: Washington, DC. 